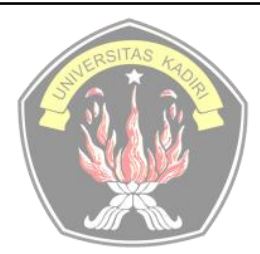

Tersedia online di

"http://ojs.unik-kediri.ac.id/index.php/ekonika"

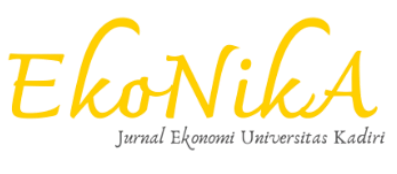

\title{
The Determinants Of Happiness: Empirical Evidence Of Java Island
}

Dewi Nandini ${ }^{1}$, Bambang Eko Afiatno ${ }^{2}$

Airlangga Universitu, Surabaya, Indonesia

email: ${ }^{1}$ dewinandini@gmail.com, ${ }^{2}$ afiatno@yahoo.com

\section{Artikel History:}

Artikel masuk

Artikel revisi

Artikel diterima

\section{Keywords:}

Maksimum 5 kata kunci

Style APA dalam mensitasi artikel ini: [Heading sitasi] Satu, N. P., \& Dua, N. P. (Tahun). Judul Artikel. Ekonika : Jurnal Ekonomi Universitas Kadiri, v(n), Halaman awal Halaman akhir. [heading Isi sitasi]

\begin{tabular}{l}
\hline ABSTRAK \\
\hline Penelitian tentang kebahagiaan di bidang ekonomi semakin \\
berkembang sejak kemunculan Easterlin Paradox. Studi ini \\
bertujuan untuk menganalisis determinan kebahagiaan di Pulau \\
Jawa, Indonesia. Data bersumber dari Survei Pengukuran Tingkat \\
Kebahagiaan (SPTK) 2017 yang dilaksanakan oleh BPS dengan \\
mengambil observasi sebesar 23.456 responden. Sebanyak 13 \\
variabel bebas diuji pengaruhnya terhadap kebahagiaan dengan \\
menggunakan analisis regresi logistik biner. Hasil penelitian \\
menunjukkan bahwa pendapatan, pendidikan, kesehatan, \\
hubungan sosial dengan keluarga dan masyarakat, kondisi \\
lingkungan, serta kehidupan yang bermakna berpengaruh terhadap \\
kebahagiaan. Secara umum temuan ini memperkuat beberapa \\
temuan dari penelitian-penelitian sebelumnya. \\
Kata Kunci: kebahagiaan, subjective well-being, regresi logistik \\
biner
\end{tabular}

ABSTRACT

Happiness research on economics has increasingly developed since Easterlin Paradox appeared. This research tries to analyze the determinants of happiness in Java Island, Indonesia. We use data from the Happiness Measurement Survey 2017 conducted by the BPS-Statistic Agency of Indonesia. Taking 23,456 observations, we employ binary logistic regression to test the effects of 13 independent variables on happiness. The results showed that income, education, health, social relations with family and society, environmental conditions, and a meaningful life affected happiness. In general, these findings strengthen some previous studies findings.

Keyword: happiness, subjective well-being, binary logistic regression

\section{BACKGROUND}

Development progress has been more likely related to economic measurements and indicators such as poverty and economic growth for a long time. Gross National Product (GNP) is considered a very representative aggregate measure in reflecting the country's welfare (Frey 
\& Stutzer, 2018; Sohn, 2010). The relationship between per capita income and well-being has long been familiar in economics. Communities with higher income levels will have easier access to better living facilities. However, in the last few decades, an idea arose that economic growth and income were not sufficient indicators to describe development progress in a country (Clark, 2018).

Diener and Seligman (2004) denoted that even though the economy grew well in the last few decades, this growth was not followed by increasing life satisfaction in the same period. This phenomenon has been examined by Easterlin (1974) on his research in America, which found that increasing income is not followed by increasing happiness. This finding became known as Easterlin Paradox. We can also link this phenomenon to the suicide rate. World Bank data shows that suicide rates in high-income countries are higher than in middle-lower-income countries (see Figure 1).

Figure 1. Comparison of World Suicide Rate

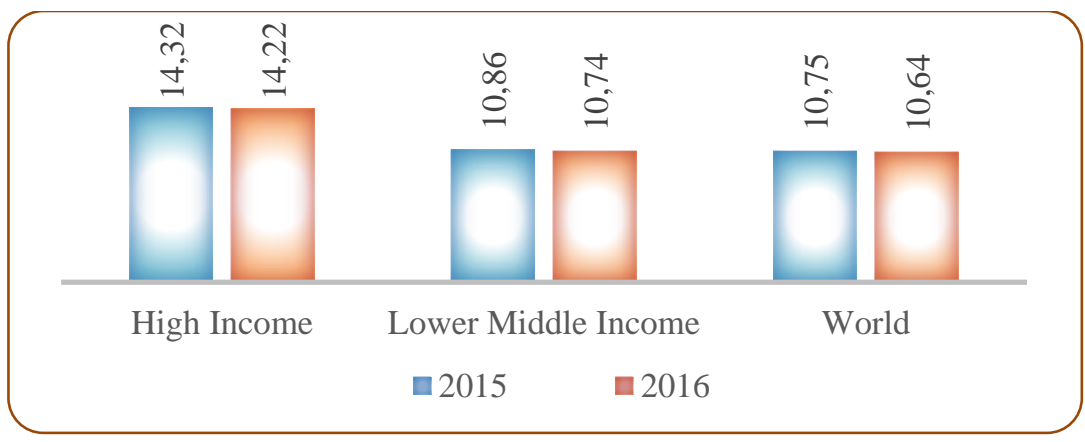

Source: World Bank, processed (http://data.worldbank.org)

Eventually, some experts and government officials not only began to realize the importance of measuring welfare that was not only based on income but also encouraged the thoughts about measuring welfare in more representative ways (Forgeard, Jayawickreme, Kern, \& Seligman, 2011). We can not only assess human welfare materially, but also have to pay attention to the quality of relationships with others, the pleasant feeling because of sharing with others, the comfortable natural environment, and good governance (Johns \& Ormerod, 2007). It has increasingly recognized that it is crucial to find welfare measures that not only based on economic measures but also led to "subjective well-being" conditions (Forgeard et al., 2011; Frey dan Stutzer, 2018; Graham, 2011).

The study of happiness has increasingly developed and carried out by various experts, including economists. Economists focused on researches and debates on how happiness could be a proxy for the utility, which was the central concept of well-being (Graham, 2011). These did not mean ignoring macro indicators that have long been used as development achievements. 
The happiness measured was expected to complement other macro indicators in measuring development achievements that could be comparable across countries (Forgeard et al., 2011; Frey \& Stutzer, 2018; Graham, 2011).

Debates on happiness research also occurred in how happiness should be measured. Most researchers agreed that happiness was slightly complicated and led to various definitions (Gasper, 2010). Different studies defined happiness in different ways, so that it raised unclear, overly broad definitions and a variety of terms such as well-being, happiness, quality of life, and life satisfaction. Diener and Seligman (2004) argued that a more systematic approach is needed to measure happiness. Some researchers sometimes disregarded this term diversity and assumed these terms could use interchangeably.

The Organization of Economic Cooperation and Development (OECD) has developed a framework for better welfare measurement in the publication "How's Life? Measuring WellBeing". The measurement involves various indicators of different types of capital, namely economic capital, natural capital, human capital, and social capital (OECD, 2011). Adapting the OECD framework, the BPS-Statistic Agency of Indonesia contributed to happiness data provision in Indonesia through Happiness Measurement Survey (Survei Pengukuran Tingkat Kebahagiaan/SPTK) in 2014 and 2017. This survey describes the level of subjective happiness related to life aspects that are considered to be relevant and meaningful. These aspects covered three major dimensions, namely (1) evaluation of the ten domains of human life that are considered to be essential/important by the majority of the population, (2) affect (feelings or emotional conditions), and (3) eudaimonia (meaning of life) (meaning of life) (BPS, 2017).

We consider that subjective well-being in Indonesia is very interesting for further discussion. Several studies of happiness determinants in Indonesia have been carried out previously using data from the 2007 Indonesian Family Life Survey (IFLS). However, to the best of our knowledge, there has been no happiness research that uses the 2017 SPTK data from BPS, which focuses on Java. The 2017 SPTK samples are spread throughout provinces in Indonesia so that the data will be more representative in describing happiness in Indonesia. In this study, researchers will analyze the determinants of subjective well-being (henceforth, we will use the term "happiness"), which focus on provinces in Java Island.

Java is the most populous island in Indonesia which occupied by 56.62 percent of Indonesia's population. In 2018, this $129.438 \mathrm{~km}^{2}$ island must accommodate 146.68 million people, so that it has a population density of $1,156.04$ people $/ \mathrm{km}^{2}$ (BPS, 2019). Not only as of the center of government, but Java is also the center of most economic activities in Indonesia, 
which contributed to 58.48 percent of Indonesia's Gross Domestic Product (GDP) in 2018 (BPS, 2019).

\section{LITERATURE REVIEW}

\section{Happiness on Economic View}

In economic literature, happiness has a close relation to consumer satisfaction, which is known as a utility. The utility concept is defined as a measure (numerical score) of the relative satisfaction level obtained by consumers from the consumption of goods and services (Pyndick \& Rubinfeld, 2013; Sexton, Fortura, \& Kovacs, 2016). In everyday life, we uasually call a utility as a benefit or well-being (Pyndick \& Rubinfeld, 2013). Nicholson and Snyder (2012) state that utility refers to overall satisfaction, which is influenced by various factors so that the measurement is always assumed to be ceteris paribus (other things being equal). Besides, the utility is also closely related to consumer preferences, so the measurement must meet the characteristics of consumer preferences, namely completeness, transitivity, and continuity (Nicholson \& Snyder, 2012).

Subjectivity in utility concept allows someone to express his opinion about the happiness or satisfaction of life they experience (Frey \& Stutzer, 2002). Happiness measurement can be considered into categorical data (ordinal) and analyzed with econometrics. Higher grades are assumed to represent a higher level of happiness. The econometric function of happiness can be written as follows:

$$
Y_{i t}=\alpha+\beta X_{i t}+\varepsilon_{i t}
$$

Where $Y_{i t}$ is the level happiness of individual $i$ at time $t$, whereas $X_{i t}$ is the socioeconomic variables of individual $i$ at time $t$.

Meanwhile, the concept of happiness is known as a concept with an expansive and complex definition. Besides, the definition of happiness is very subjective that only an individual felt himself. This subjectivity makes measuring happiness more difficult. According to Veenhoven (1988), there are three theories of happiness as follows:

1. Set-point theory, happiness is considered as something that has been determined (influenced by genetics and culture) and does not depend on a person's ways of life.

2. Cognitive theory, happiness is considered as a person's thoughts and reactions to the difference between reality and hope in his life.

3. Affective theory, happiness is considered as a reflection of the person's good and bad life in general. 
into three traditional theories and one modern theory. The hedonism theory said that happiness is maximizing pleasure and minimizing pain. The desire theory explained happiness as the realization of one's desires. Objective list theory stated that happiness is if we could reach the target and life goals. Moreover, the authentic theory said that happiness includes pleasant life/pleasure, good life, and meaningful life). On economic studies, there are more various terms to describe happiness, including subjective well-being and life satisfaction. In their application, the terms replace each other, but Graham (2011) said there are fundamental meanings to these three terms:

1. Happiness generally represents how happy someone is; respondents are not limited to a particular definition and can define happiness according to their standards.

2. Life satisfaction has a smaller scope and closer to income, but the response to this question is generally similar to happiness.

3. Subjective well-being includes all the ways a person states his welfare, which covers satisfaction to different aspects of life, such as work, health, education, and others.

According to Frey and Stutzer (2018), we could use several methods to measure happiness, namely surveys, brain activity, day reconstruction method, and U-index. Among these methods, the survey method is the most widely used. Some examples of happiness surveys are the General Social Survey, the World Value Survey, and The Eurobarometer Survey. At the same time, other methods are rarely used because it requires a longer time and higher cost.

\section{Earlier Studies}

An interest in the study of happiness in economics began with the emergence of Richard Easterlin's research in America in 1974 (Frey \& Stutzer, 2002). As happiness studies develop rapidly in various science, especially in the economy, governments all over the world are increasingly aware of and begin using happiness data in public policy decisions. Increased happiness can be considered as an appropriate indicator to measure social progress and public policy goals (Helliwell, Layard, \& Sachs, 2015). The happiness studies in economics mostly analyze to find determinants of happiness by using the ordered probit technique as an analysis tool.

Several researchers conducted studies on the determinants of happiness in Indonesia, namely Landiyanto et al. (2011), Sohn (2010), Rahayu (2016), and Aryogi and Wulansari (2016). Those four studies used the 2007 IFLS data. Those four studies used the 2007 IFLS data. The variables used in those studies were almost the same, but there were differences in the variables defining and observation numbers. In general, the results of the study are relatively 
similar, that a person will be happier if he has better health conditions, better educated, lives in an urban area, married, and has a higher income. Higher assets, better social relationships, and a sound government system also make someone happier. Meanwhile, age has U-shaped influences on happiness.

Research on the determinants of happiness in several countries has more varied units of observation. Research by Chyi and Mao (2012) examined the determinants of happiness, which focused on 1,533 Chinese residents aged 60 years and over. The study analyzed data from the 2005 Chinese General Social Survey using ordered probit techniques with instrumental variables. The elderly in China feel happier if they have high incomes, large houses, live in villages, and live with grandchildren.

Another study by Senasu and Singhapakdi (2017) using telephone interview data based on a questionnaire developed by the Japan International Cooperation Agency, analyzed the happiness' determinants of 1,004 respondents in Thailand. The results show that younger, better educated, and high-income people tend to be happier. Also, health status influences happiness in more religious people.

Similar studies were also carried out by Knight et al. (2009) and Appleton and Song (2008). Both studies analyzed the determinants of happiness in mainland China, but the focus and data sets used by those two studies were different. Knight et al. focus on rural Chinese populations while Appleton and Song focus on urban populations. Some of the same things from both studies are in both urban and rural areas one is happier if he has a higher income, is married, and has good social relations with his family and society.

Other research by Eren and Asici (2017) includes a variable comparison of current life with the previous five years of life, a view of money (materialism attitude), and expectations of a future life as a proxy for psychological well-being. The results of this research indicate that materialistic attitudes lead to unhappiness. Conversely, someone tends to be happier if they have better hopes and expectations in the future.

\section{METHODS}

\section{Data Source}

This research is a quantitative-based study by utilizing microdata from the 2017 Happiness Measurement Survey (SPTK). We use binary logistic regression to estimate the determinants of happiness. SPTK 2017 is one of the surveys conducted by BPS-Statistic Agency of Indonesia to calculate a happiness index. This survey only interviews the head of the household or his partner because he was considered to have better knowledge about the 
condition of his household. Respondents were interviewed by trained officers using a questionnaire.

In total, SPTK 2017 consists of 75,000 household samples and spread evenly on all provinces of Indonesia. Samples were randomly selected using the two-stage-one-phasesampling method. This survey successfully recorded 72,317 households. The observations in this study will focus on the provinces in Java. From the overall responses sample, there were 23,456 observations in six provinces in Java.

\section{Variables and Research Model}

The independent variables in this study are "generally how happy the sample is." In the SPTK 2017 questionnaire, this question asks respondents to rate their overall happiness in life, by giving a score of $0-10$. A value of 0 indicates the worst condition, and 10 indicates the best condition. Nevertheless, to simplify the analysis, in this study, the data were reclassified into binary form (happy for a score of 6-10 and not happy for a score of 0-5). Meanwhile, we will analyze 13 independent variables for their effects on happiness. They are 1) age, 2) quadratic age, 3) marital status, 4) health status, 5) presence/absence of chronic disease, 6) education, 7) classification residence, 8) homeownership, 9) monthly household income, 10) family harmony, 11) social relationships, 12) environmental conditions, and 13) meaning of life (eudaimonia).

Age and age squares are ratio scaled. Age is the age of respondents based on their last birthday. Quadratic elements are included to see whether the age variable has an effect on Ushaped, like the majority of previous studies. Marital status is divided into two, married and single - the single consists of respondents who are single and divorced. The respondent's health condition was approached with two variables, health status and the presence of chronic disease. Health status represents the intensity of respondents experiencing physical disorders due to symptoms of the disease, which is categorized as healthy and unhealthy. Meanwhile, chronic diseases are diseases that require a relatively long time to appear or cure. This variable is categorized as present and absent.

Education represents the highest level of education completed by respondents. This variable is categorized as less than junior high school and senior high school above. Classification of residence is a classification of the area of residence of the respondent, in rural or urban areas. Homeownership is ownership of residential buildings occupied by respondents and their households, which are categorized as their own and not their own. Monthly household income is the average income earned by all household members, which is categorized under/equal to $\operatorname{Rp~1,800,000~and~above~} \operatorname{Rp} 1,800,000$. 
Meanwhile, family relationships represent respondents' satisfaction with the harmony of their families. In this variable, family harmony includes three things, cohesiveness, trust in the family, and sufficient time for joint activities. Social relationships are respondents' satisfaction with relationships with the surrounding community. This social relationship is related to harmony and the opportunity to socialize with residents around the respondent's residence. Environmental conditions indicate respondents' satisfaction with the environmental conditions of their homes, which include water quality, air quality, and disaster events. The meaning of life (eudaimonia) is the respondent's assessment of the meaning of life. It includes independence, environmental mastery, self-development, positive relationships with others, life goals, and self-acceptance. Like the independent variables, on these four variables, the respondent was asked to give a score of $0-10$, which illustrates his perception. However, in this research these four variables will be categorized binary (code 0 for score $0-5$, and code 1 for score 6-10). Overall the variables used in this study are presented in the following Table 1.

Table 1. Variable's Definitions

\begin{tabular}{|c|c|c|c|c|}
\hline No. & Variable Name & Definition & Symbol & Categorization \\
\hline (1) & (2) & (3) & (4) & $(5)$ \\
\hline \multicolumn{5}{|c|}{ Dependent Variables } \\
\hline 1. & Happiness & $\begin{array}{l}\text { Respondent's assessment } \\
\text { of general happiness in life }\end{array}$ & happy & $\begin{array}{l}0=\text { unhappy } \\
1=\text { happy }\end{array}$ \\
\hline \multicolumn{5}{|c|}{ Independent Variables } \\
\hline 1. & Age & $\begin{array}{l}\text { Respondent's age } \\
\text { according to their last } \\
\text { birthday }\end{array}$ & age, age ${ }^{2}$ & - \\
\hline 2. & Marital status & Respondent's marital status & married & $\begin{array}{l}0=\text { no } \\
1=\text { yes }\end{array}$ \\
\hline 3. & Education & $\begin{array}{l}\text { Respondent's highest } \\
\text { completed education level }\end{array}$ & education & $\begin{array}{l}0=\leq \text { junior high school } \\
1=\geq \text { senior high school }\end{array}$ \\
\hline 4. & $\begin{array}{l}\text { Residence } \\
\text { classification }\end{array}$ & $\begin{array}{l}\text { Respondent's residence } \\
\text { classification, urban or } \\
\text { rural }\end{array}$ & urban & $\begin{array}{l}0=\text { no } \\
1=\text { yes }\end{array}$ \\
\hline 5. & Health status & $\begin{array}{l}\text { Intensity of health } \\
\text { problems for the past six } \\
\text { months }\end{array}$ & sick & $\begin{array}{l}0=\text { often/highly often } \\
1=\text { never/rarely }\end{array}$ \\
\hline 6. & Chronic disease & $\begin{array}{l}\text { The presence of chronic } \\
\text { disease }\end{array}$ & chronic & $\begin{array}{l}0=\text { yes } \\
1=\text { no }\end{array}$ \\
\hline 7. & $\begin{array}{l}\text { Household } \\
\text { income }\end{array}$ & $\begin{array}{l}\text { Total income (money and } \\
\text { goods) obtained by all } \\
\text { household members }\end{array}$ & income & $\begin{array}{l}0=\leq 1,8 \text { million rupiahs } \\
1=>1,8 \text { million rupiahs }\end{array}$ \\
\hline 8. & Homeownership & $\begin{array}{l}\text { Ownership of residential } \\
\text { buildings occupied by } \\
\text { respondents and their } \\
\text { households }\end{array}$ & home & $\begin{array}{l}0=\text { not their own } \\
1=\text { their own }\end{array}$ \\
\hline 9. & Family harmony & $\begin{array}{l}\text { Respondent's satisfaction } \\
\text { of family harmony }\end{array}$ & family & $\begin{array}{l}0=\text { not satisfied } \\
1=\text { satisfied }\end{array}$ \\
\hline
\end{tabular}




\begin{tabular}{|c|l|l|l|l|}
\hline No. & Variable Name & \multicolumn{1}{|c|}{ Definition } & \multicolumn{1}{c|}{ Symbol } & \multicolumn{1}{c|}{ Categorization } \\
\hline$(1)$ & \multicolumn{1}{|c|}{$(2)$} & \multicolumn{1}{c|}{$(3)$} & \multicolumn{1}{c|}{$(5)$} \\
\hline 10. & $\begin{array}{l}\text { Social } \\
\text { relationship }\end{array}$ & $\begin{array}{l}\text { Respondent's satisfaction } \\
\text { of social relations with } \\
\text { their neighborhood } \\
\text { residents }\end{array}$ & social & $\begin{array}{l}0=\text { not satisfied } \\
1=\text { satisfied }\end{array}$ \\
\hline 11. & $\begin{array}{l}\text { Environmental } \\
\text { conditions }\end{array}$ & $\begin{array}{l}\text { Respondent's assessment } \\
\text { of the environment around } \\
\text { their residence }\end{array}$ & environment & $\begin{array}{l}0=\text { not satisfied } \\
1=\text { satisfied }\end{array}$ \\
\hline 12. & Meaning of life & $\begin{array}{l}\text { Respondent's assessment } \\
\text { of their meaning of life }\end{array}$ & eudaimonia & $\begin{array}{l}0=\text { meaningless } \\
1=\text { meaningful }\end{array}$ \\
\hline
\end{tabular}

This study employs binary logistic analysis to determine the effect of independent variables on dependent variables. This analysis allows modeling in cases the dependent variable has two categories. By applying binary logistic regression, we can obtain the probability of an event affected by independent variables. We use Stata 13.0 software to process the data. The model can be written as follows:

$$
\begin{aligned}
& \ln \left(\frac{P}{1-P}\right)=\beta_{0}+\beta_{1} \text { age }+\beta_{2} \text { age } 2+\beta_{3} \text { education }+\beta_{4} \text { married }+\beta_{5} \text { urban }+\beta_{6} \text { sick }+ \\
& \beta_{7} \text { chronic }+\beta_{8} \text { income }+\beta_{9} \text { home }+\beta_{10} \text { family }+\beta_{11} \text { social }+ \\
& \beta_{12} \text { environment }+\beta_{13} \text { eudaimonia }+\varepsilon
\end{aligned}
$$

In binary logistics analysis, there are several tests to assess whether the model is meaningful or not, simultaneously and partially. The simultaneous test is used to determine whether all independent variables together affect the dependent variable, using the $\mathrm{G}^{2}$ statistical test (likelihood ratio test) as follows:

$$
G=-2 \ln \frac{L_{0}}{L_{1}}
$$

Where:

$L_{o}=$ likelihood without independent variables

$L_{1}=$ likelihood with all independent variables

Meanwhile, the partial test is used to determine whether each independent variable affects the dependent variable, using Wald statistical test as follows:

$$
W_{j}=\left(\frac{\beta_{j}}{\operatorname{se}\left(\beta_{j}\right)}\right)^{2}
$$

Where $j=1,2,3, \ldots, k$ ( $k=$ number of independent variables $)$.

\section{RESULTS}


The happiness index is an index compiled by BPS to describe happiness in Indonesia based on SPTK data. The index is expressed on a scale of 0-100. So far, BPS has released the happiness index twice in 2014 and 2017. The methods used in preparing the 2017 happiness index are different from those used in the 2014 happiness index. In 2014, the happiness index was only based on life satisfaction dimensions. Meanwhile, the 2017 happiness index is formed from three dimensions, 1) the life satisfaction dimension, 2) the affect dimension (feeling/emotional), and 3) the meaning of life dimension (eudaimonia).

In 2017, Indonesia's happiness index was 70.69 and was declared as quite happy (BPS, 2017). Most provinces (24 provinces) have a happiness index above the national index. The province with the highest happiness index is North Maluku, while the province with the lowest happiness index is Papua. Comparison of happiness index for the provinces in Java can be seen in the following Figure 2. DI Yogyakarta is a province in Java which has the highest happiness index.

Figure 2. 2017 Happiness Index Comparison

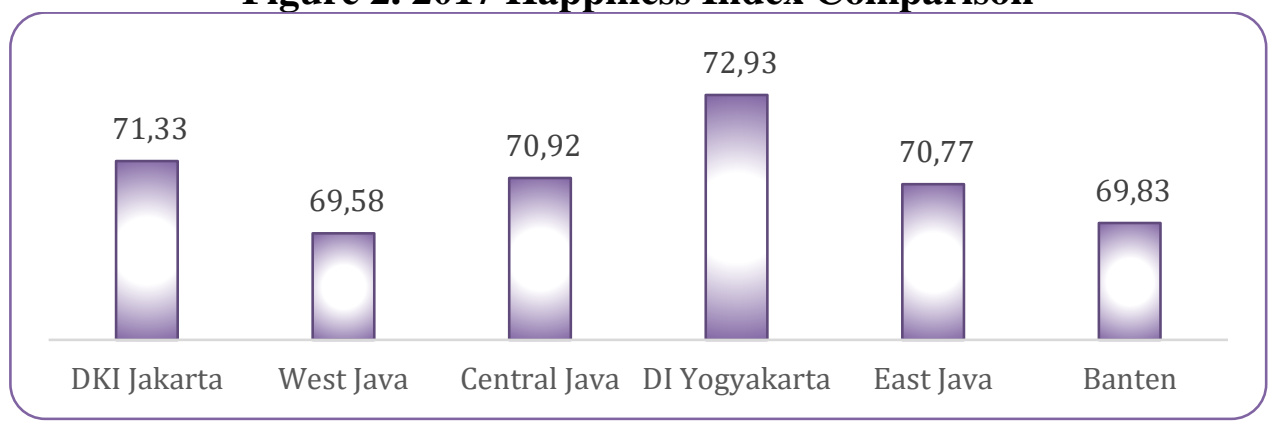

Source : BPS (2017), processed

Figure 3 below shows the dimensions of the happiness index in six provinces located in Java Island. Among the three dimensions, the index of affect dimension has the smallest index value compared to the other dimensions. A similar pattern is found in five provinces except for DI Yogyakarta. Sequentially the highest index value in the DI Yogyakarta Province is the meaning of life dimension, affect dimension, and life satisfaction dimension. Whereas in general, the pattern in the other five provinces shows that affect dimension has the lowest index value.

Figure 3. Comparison of The Dimensions of 2017 Happiness Index 


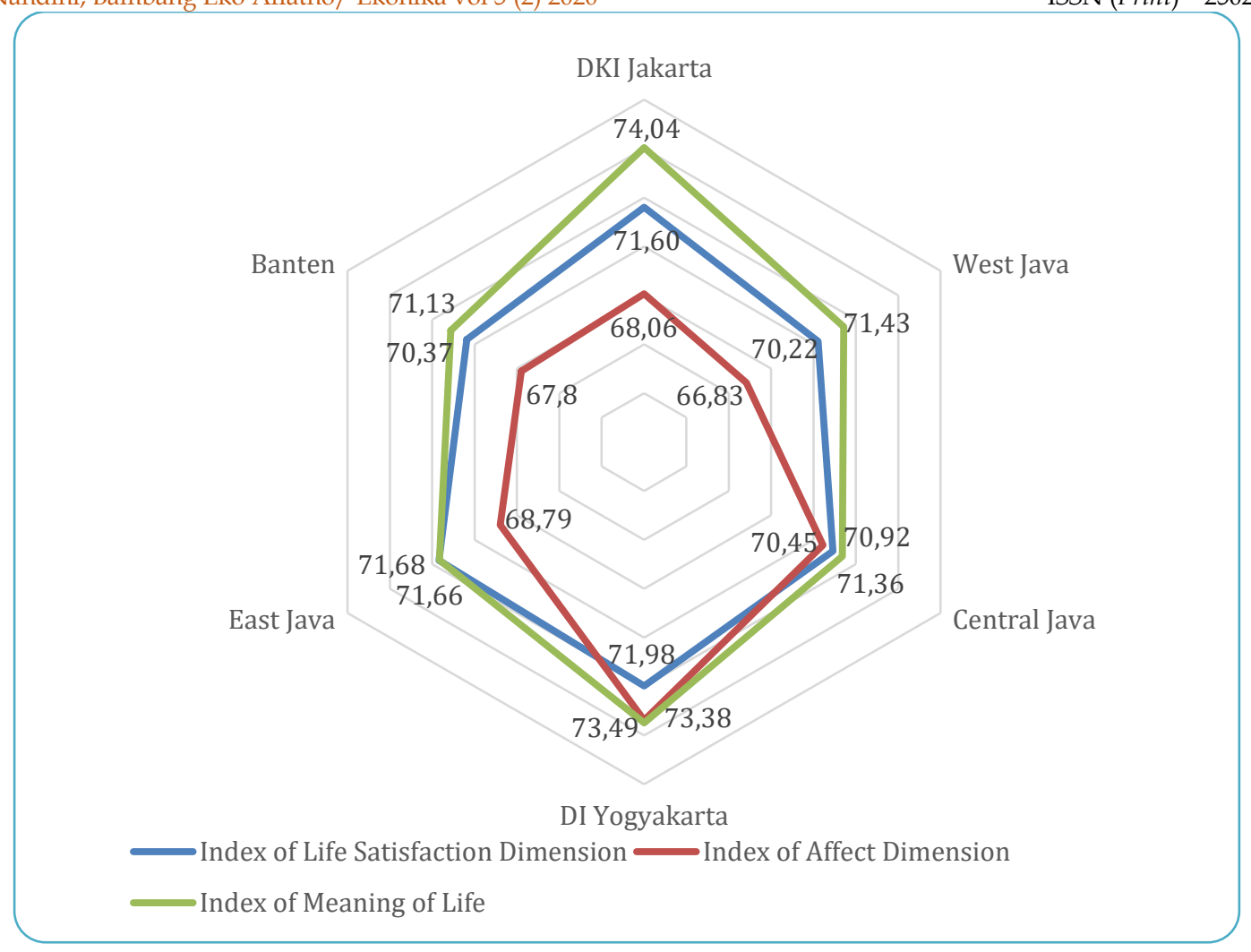

Source : BPS (2017), processed

Table 3 below shows the results of logistic regression estimation. As explained earlier, simultaneous and partial tests are needed to see whether the model formed is good or not. The simultaneous test shows a significant probability value (p-value) $(<0.01)$, which means that the independent variable influences the dependent variable. The Pseudo-R2 value indicates the effects of the simultaneous influence of the independent variables on the dependent variable. The test shows the value of 0.2126 , which means that all independent variables give an effect of 21.26 percent to the dependent variable, while other variables influence the remaining 78.74 percent. The partial test also shows significant results ( $p$-value $<0.01$ ), which indicates that each independent variable included in the model affects the dependent variable.

In Table 3, column 4 shows the odds ratio, which shows the probability of the characteristics of the independent variable for happiness. Marital status shows significant results in the model. This result is in line with several previous studies (Frijters, HaiskenDeNew, \& Shields, 2004; Kalyuzhnova \& Kambhampati, 2008; Knight et al., 2009; Sohn, 2010). The odds of a married respondent being happy compared to a single respondent is 1,2638, which means marrying people more likely to be happy. According to Frey and Stutzer (2018) marriage can be a counterweight and reduce stress feelings because of work and loneliness. Economically, marriage also provides financial guarantees in the adverse economic conditions, and also provide higher capital accumulation (Stutzer \& Frey, 2006). 
Table 3. Binary Logistic Regression Results

\begin{tabular}{lllc}
\hline \multicolumn{1}{c}{ Independent Varaibles } & \multicolumn{1}{c}{ Symbol } & \multicolumn{1}{c}{$\boldsymbol{\beta}$} & Odds Ratio \\
\hline Intercept & \multicolumn{1}{c}{$(2)$} & $(3)$ & $(4)$ \\
\hline Age & $\mathrm{B}_{0}$ & $-1.4300^{*}$ & 0.2393 \\
\hline Age Square & age & $-0.0910^{*}$ & 0.9129 \\
\hline Marital status & age $^{2}$ & $0.0009^{*}$ & 1.0009 \\
\hline Education & married & $0.2341^{*}$ & 1.2638 \\
\hline Residence classification & education & $0.6101^{*}$ & 1.8406 \\
\hline Health status & urban & $0.1968^{*}$ & 1.2174 \\
\hline Chronic disease & sick & $0.4184^{*}$ & 1.5194 \\
\hline Household income & chronic & $0.2769^{*}$ & 1.3191 \\
\hline Homeownership & income & $0.6740^{*}$ & 1.9621 \\
\hline Family harmony & home & $0.3149^{*}$ & 1.3701 \\
\hline Social relationship & family & $1.4770^{*}$ & 4.3799 \\
\hline Environmental condition & social & $0.7344^{*}$ & 2.0842 \\
\hline Meaning of life & environment & $0.7682^{*}$ & 2.1559 \\
\hline * (significant on $\boldsymbol{\alpha}=\mathbf{0 . 0 1 )}$ & eudaimonia & $1.9846^{*}$ & 7.2758 \\
\hline Pseudo $\mathbf{R}^{\mathbf{2}}=\mathbf{0 . 2 1 2 6}$ & & & \\
\hline Number of observations $=\mathbf{2 3 , 4 5 6}$ & & \\
\hline Source: 2017 SPTK raw data, processed & & \\
\hline
\end{tabular}

The level of education also shows significant results, supporting the research by Chyi and Mao (2012), Landiyanto, et al. (2011), also Senasu and Singhapakdi (2017). The odds of respondent graduated from high school and above being happy compared to those who graduated from junior high school or below is 1.8406, which means higher education people are more likely to be happy. By reaching higher education, people will have better opportunities and broader networks in employment (Chen, 2012; Frey \& Stutzer, 2018). The odds of the urban respondent being happy compared to the rural respondent is 1.2174 , which means that urban people are more likely to be happy. This result is contrary to Hudson (2006), Gerdtham (2001), and Graham and Felton (2006) who find that someone who lives in a big city reports lower happiness. However, according to Sohn (2010), Indonesian urban people are happier because they tend to be more educated than rural people.

Health has a positive effect on happiness. People with better health conditions tend to be happier than those who do not (Oswald \& Powdthavee, 2008; Shields \& Price, 2005). The odds of respondents who have never/rarely been sick in being happy compared to those who frequently/highly often get sick is 1.5194 , which means healthy people are more likely to be happy. In addition, respondents who did not have chronic disease had a 1.3191 higher 

findings of Fijters et.al (2004), Sohn (2010), and Landiyanto et.al (2011).

Happiness research on economic mostly includes income variables. The estimation results show that respondents with higher household income are 1,9621 times more likely to be happier than respondents with lower income. This result is in line with many studies, including Appleton and Song (2008), Chyi and Mao (2012), also Eren and Asici (2017). However, at a certain point, the increase in happiness will be smaller as income increases (Johns \& Ormerod, 2007). Also, materialistic leads to unhappiness (Eren \& Aş1c1, 2017; Frey \& Stutzer, 2018). Besides, respondents who own their own homes have a probability of 1.3701 times happier than respondents who do not have their own homes. This finding is in line with the findings of Chyi and Mao (2012) which show that homeownership has a positive effect on happiness.

The odds of respondents who were satisfied with the harmony of their families compared to those who were dissatisfied are 4.3799, which means people are more likely to be happy if they have good relationships among families. Likewise, respondents who are satisfied with their social relations have a probability of 2.0842 times happier than dissatisfied respondents. These show that good social relations with family and society are essential aspects that influence happiness (Frey \& Stutzer, 2018; Knight et al., 2009; Sohn, 2010). An excellent social relationship is also a source of social capital formation. BPS $(2010,2016)$ said that social capital is a form of horizontal human relations that can affect community productivity. In several studies, social capital has a positive impact on happiness (Bartolini \& Bilancini, 2010; Sarracino, 2012; Tokuda, Fujii, \& Inoguchi, 2010).

Veenhoven (2000) states that environmental feasibility reflects environmental quality where people can get what they need. Not only nature, but the feasibility of the environment also includes social life in it. Respondents who are satisfied with their environment condition have a probability of 2.1559 times happier than dissatisfied respondents. Also, the odds of respondents who feel meaningful life compared to those who have a meaningless life is 7.2758 , means that people are more likely to be happy if their life feels meaningful. Eren and Asici (2017) include proxy variables for psychological well-being in their research and found that hopes and expectations for a better future will make people happier.

\section{CONCLUSION AND SUGGESTION}

This study tries to examine the determinants of happiness in Indonesia, which focused on the provinces in Java Island. The results found that the factors that can increase the probability of happiness are higher education, higher income, living in urban areas, better 
health, owning a home, living conditions, harmonious family, good social relationships, and psychologically feel meaningful life. Meanwhile, age affects happiness in the U-shaped. These findings also strengthen the previous findings.

Attention to happiness becomes essential for policymakers because happiness is expected to be a measure that can complement other macroeconomic indicators to reflect the country's achievement. Health and education are still essential aspects that the community and government must pay attention to them. The central and regional governments can guarantee the availability of qualified and affordable health and education facilities so that they can develop the quality of human resources in Java. However, the community must also be responsible for maintaining health with a healthy lifestyle and nutritious food.

As the most populous island in Indonesia, it is undeniable that Java has a severe problem in the environment feasibility, especially in the capital city at each province. An overcrowded environment always leads to an abundance of garbage, which can lead to floods. Not only that, increasing forest destruction potency for housing and agricultural purposes can endanger forest sustainability and cause natural disasters. Moreover, it also requires joint efforts to maintain family harmony and good social relations relationship. Good social relationships will foster social capital in the community and create a more productive community in supporting development.

One limitation of this research lies in the data used. 2017 SPTK data does not reflect the happiness of each individual. This problem makes 2017 SPTK less representative for a more specific analysis of happiness. Another limitation of this study is the use of cross-section data, so there is no way to see the trend of happiness in Indonesia. The analytical tool used also tends to be simpler than previous studies so that in the future, it is better to employ better estimation techniques.

\section{BIBLIOGRAPHY}

Appleton, S., \& Song, L. (2008). Life Satisfaction in Urban China: Components and Determinants. World Development, 36(11), 2325-2340. https://doi.org/10.1016/j.worlddev.2008.04.009

Aryogi, I., \& Wulansari, D. (2016). Subjective Well-being Individu dalam Rumah Tangga Di Indonesia. Jurnal Ilmu Ekonomi Terapan, 01(1), 1-12.

Bartolini, S., \& Bilancini, E. (2010). If not only GDP, what else? Using relational goods to predict the trends of subjective well-being. International Review of Economics, 57(2), 199-213. https://doi.org/10.1007/s12232-010-0098-1

BPS. (2010). Stok Modal Sosial 2009. Jakarta.

BPS. (2016). Statistik Modal Sosial 2014. Jakarta. 
BPS. (2017). Indeks kebahagiaan 2017. Jakarta: Badan Pusat Statistik.

BPS. (2019). Statistik Indonesia 2019. Jakarta: Badan Pusat Statistik.

Chen, W. chi. (2012). How Education Enhances Happiness: Comparison of Mediating Factors in Four East Asian Countries. Social Indicators Research, 106(1), 117-131. https://doi.org/10.1007/s11205-011-9798-5

Chyi, H., \& Mao, S. (2012). The Determinants of Happiness of China's Elderly Population. Journal of Happiness Studies, 13(1), 167-185. https://doi.org/10.1007/s10902-011-92568

Clark, A. E. . et. a. (2018). The Origins of Happiness : The Science of Well-Being over The Life Course. https://doi.org/10.1017/CBO9781107415324.004

Diener, E., \& Seligman, M. E. P. (2004). Beyond Money: Toward an Economy of WellBeing. Psychological Science in the Public Interest, 5(1), 1-31. https://doi.org/10.1111/j.0963-7214.2004.00501001.x

Easterlin, R. A. (1974). Does Economic Growth Improve the Human Lot? Some Empirical Evidence. In Nations and Households in Economic Growth. https://doi.org/10.1016/b978-0-12-205050-3.50008-7

Eren, K. A., \& Aş1c1, A. A. (2017). The Determinants of Happiness in Turkey: Evidence from City-Level Data. Journal of Happiness Studies, 18(3), 647-669. https://doi.org/10.1007/s10902-016-9746-9

Forgeard, M. J. C., Jayawickreme, E., Kern, M. L., \& Seligman, M. E. P. (2011). Doing the right thing: Measuring wellbeing for public policy. 1, 79-106. https://doi.org/10.5502/ijw.v1i1.15

Frey, B. S., \& Stutzer, A. (2002). What Can Economists Learn from Happiness Research? Journal of Economic Literature, 40, 402-435. https://doi.org/10.1257/jel.40.2.402

Frey, B. S., \& Stutzer, A. (2018). Economics of Happiness. Springer International Publishing.

Frijters, P., Haisken-DeNew, J. P., \& Shields, M. A. (2004). Investigating the patterns and determinants of life satisfaction in Germany following reunification. Journal of Human Resources, 39(3), 649-674. https://doi.org/10.3368/jhr.xxxix.3.649

Gasper, D. (2010). Understanding the diversity of conceptions of well-being and quality of life. Journal of Socio-Economics, 39(3), 351-360. https://doi.org/10.1016/j.socec.2009.11.006

Gerdtham, U. G., \& Johannesson, M. (2001). The relationship between happiness, health, and socio-economic factors: Results based on Swedish microdata. Journal of SocioEconomics, 30(6), 553-557. https://doi.org/10.1016/S1053-5357(01)00118-4

Graham, C. (2011). The Pursuit of Happiness : An Economy of Well-Being. Washington DC: Brookings Institution Press.

Graham, C., \& Felton, A. (2006). Inequality and happiness: Insights from Latin America. Journal of Economic Inequality, 4, 107-122. https://doi.org/10.1007/s10888-005-9009-1

Helliwell, J., Layard, R., \& Sachs, J. (2015). World Happiness Report 2015. Retrieved from http://eprints.lse.ac.uk/47487/

Hudson, J. (2006). Institutional trust and subjective well-being across the EU. Kyklos, 59(1), 
43-62. https://doi.org/10.1111/j.1467-6435.2006.00319.x

Johns, H., \& Ormerod, P. (2007). Happiness, Economics, and Public Policy. https://doi.org/10.4337/9781782544371.00016

Kalyuzhnova, Y., \& Kambhampati, U. (2008). The determinants of individual happiness in Kazakhstan. Economic Systems, 32(3), 285-299. https://doi.org/10.1016/j.ecosys.2008.02.001

Knight, J., Song, L., \& Gunatilaka, R. (2009). Subjective well-being and its determinants in rural China. China Economic Review, 20(4), 635-649. https://doi.org/10.1016/j.chieco.2008.09.003

Landiyanto, E. A., Ling, J., Puspitasari, M., \& Irnanto, S. E. (2011). Wealth and Happiness : Empirical Evidence from Indonesia. Chulalongkorn Journal of Economics, 23, 1-17.

Nicholson, W., \& Snyder, C. (2012). Microeconomics Theory: Basic Principles and Extensions, Eleventh Edition. South-Western: Cengage Learning.

OECD. (2011). How's Life? https://doi.org/http://dx.doi.org/10.1787/9789264121164-en

Oswald, A. J., \& Powdthavee, N. (2008). Does happiness adapt? A longitudinal study of disability with implications for economists and judges. Journal of Public Economics, 92(5-6), 1061-1077. https://doi.org/10.1016/j.jpubeco.2008.01.002

Pyndick, R. S., \& Rubinfeld, D. L. (2013). Microeconomics Eight Edition. New Jersey: Pearson.

Rahayu, T. P. (2016). Determinan kebahagiaan di indonesia. Jurnal Ekonomi Dan Bisnis, 19(1), 149-170.

Sarracino, F. (2012). Money, Sociability and Happiness: Are Developed Countries Doomed to Social Erosion and Unhappiness?: Time-series Analysis of Social Capital and Subjective Well-being in Western Europe, Australia, Canada and Japan. Social Indicators Research, 109(2), 135-188. https://doi.org/10.1007/s11205-011-9898-2

Senasu, K., \& Singhapakdi, A. (2017). Determinants of happiness in Thailand: The moderating role of religiousness. Journal of Human Behavior in the Social Environment, 27(4), 270-290. https://doi.org/10.1080/10911359.2017.1279580

Sexton, R. L., Fortura, P. N., \& Kovacs, C. C. (2016). Exploring Microeconomics Fourth Canadian Edition. Canada: Nelson Education Ltd.

Shields, M. A., \& Price, S. W. (2005). Exploring the economic and social determinants of psychological well-being and perceived social support in England. Journal of the Royal Statistical Society. Series A: Statistics in Society, 168(3), 513-537. https://doi.org/10.1111/j.1467-985X.2005.00361.x

Sohn, K. (2010). Considering Happiness For Economic Development : Determinants of Happiness in Indonesia (No. 10-09).

Stutzer, A., \& Frey, B. S. (2006). Does marriage make people happy, or do happy people get married? Journal of Socio-Economics, 35(2), 326-347. https://doi.org/10.1016/j.socec.2005.11.043

Tokuda, Y., Fujii, S., \& Inoguchi, T. (2010). Individual and Country-Level Effects of Social Trust on Happiness: The Asia Barometer Survey. Journal of Applied Social Psychology, 40(10), 2574-2593. https://doi.org/10.1111/j.1559-1816.2010.00671.x 
Veenhoven, R. (1988). The utility of happiness. Social Indicators Research, 20(4), 333-354. https://doi.org/10.1007/BF00302332

Veenhoven, R. (2000). The Four Qualities of Life Ordering Concepts and Measures of the Good Life. Journal of Happiness Studies, 1, 1-39. https://doi.org/10.1007/978-94-0075702-8_11 